\title{
LA FIESTA DE LA CRUZ DE MAYO. SONORIDAD Y RITUALIDAD EN LOS VALLES DE ARICA
}

\author{
THE CRUZ DE MAYO FESTIVAL. SOUND AND RITUALITY IN \\ THE ARICA VALLEYS
}

Alberto Díaz Araya ${ }^{a}$ Wilson Muñoz \& Paula Martínez Sagredoc

Exponemos la importancia que posee la dimensión sociomusical de la fiesta de la Cruz de Mayo para el desarrollo de sus distintas fases rituales, a partir de la descripción y el análisis de información etnográfica recogida durante su celebración en los valles de Lluta y Codpa (Región de Arica y Parinacota). Durante dicha festividad, una de las más significativas del norte de Chile y gran parte de la zona sur andina, la ejecución de música y sonoridades populares en honor a la Santa Cruz es uno de sus aspectos más distintivos.

Palabras clave: sonoridad, ritualidad, Cruz de Mayo, Arica.

In this article we discuss the importance of the socio-musical dimension for the development of its different ritual phases of the Cruz de Mayo Festival. The description and analysis are based on ethnographic information collected during the celebration of this festival in the Lluta and Codpa valleys (Arica and Parinacota Region). A distinctive aspect of this celebration, one of the most important festivities of Northern Chile and large part of the South Andean area, is the playing of popular music and sounds in honor of the Holy Cross.

Keywords: sounds, rituality, Cruz de Mayo, Arica.

\section{INTRODUCCIÓN}

La celebración de la Cruz de Mayo corresponde a una festividad religiosa con amplia difusión en el norte de Chile y gran parte de la zona andina (Van Kessel 2006; Millones \& Tomoeda 2011). Sabemos que se incorporó tempranamente como dispositivo evangelizador en toda Latinoamérica, siendo reproducido el culto entre los indígenas como parte de un símbolo de poder sobre los territorios indígenas y en áreas de presencia de esclavos africanos (Caro Baroja 1979; Martínez 2001; Díaz et al. 2020). Desde tiempos coloniales, la fiesta en honor a la Cruz guarda una estructura interna que integra el símbolo catequístico con las devociones que las poblaciones autóctonas despliegan al momento de la conmemoración (Millones 2001: 67); incluso ha sido celebrada en el sur chileno con procesiones y dádivas a la Cruz (Sáez 2005; Uribe 2008).

Actualmente, las comunidades andinas y afrodescendientes se congregan cada mes de mayo en los pueblos, valles o sectores cordilleranos del norte chileno para realizar una serie de prácticas rituales y celebrar una cruz familiar o comunitaria erigida en un cerro

A Alberto Díaz Araya, Departamento de Ciencias Históricas y Geográficas, Universidad de Tarapacá, Arica, Chile. ORCiD: 0000-00015080-1672. E-mail: albertodiaz@academicos.uta.cl

B Wilson Muñoz, Departamento de Ciencias Históricas y Geográficas, Universidad de Tarapacá, Arica, Chile. ORCID: 0000-0002-6496500X. E-mail: wilsonsocio@gmail.com

c Paula Martínez Sagredo, Departamento de Ciencias Históricas y Geográficas, Universidad de Tarapacá, Arica, Chile. ORCID: 00000002-7881-3859. E-mail: pmartinezsagredo@gmail.com

Recibido: marzo 2020. Aceptado: noviembre 2020. 


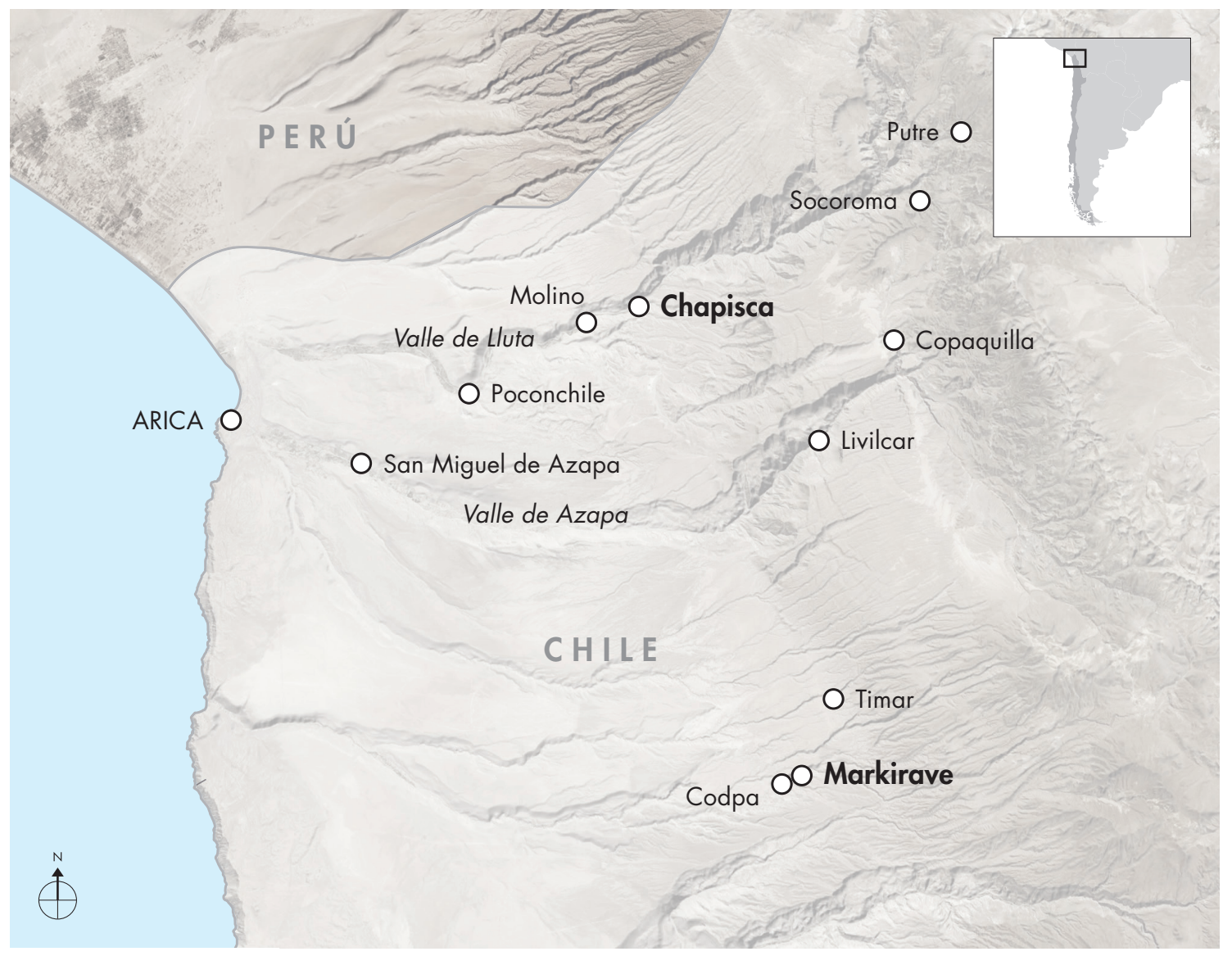

Figura 1. Mapa de las localidades mencionadas en este artículo. Figure 1. Map with the localities mentioned in this article.

próximo o en las cercanías de las chacras junto a paisajes liminales significativos y apachetas (Galdames et al. 2016). De igual forma, la fiesta de la Cruz es parte de un fenómeno mayor de congregacionalismo ritual, las que han permitido que las comunidades andinas disgregadas en las ciudades nortinas se rearticulen al retornar a sus localidades de origen para las celebraciones.

Durante esta fiesta, es clave la participación de músicos que conforman agrupaciones tales como bandas de bronces, tropas de lakitas (zampoñeros) y cantores, quienes, reunidos junto a la comunidad celebrante, desarrollan una serie de actividades rituales en honor a la Cruz con una sonoridad propia y distintiva. Al respecto, exploramos la dimensión sonora que contiene la fiesta de la Cruz de Mayo, relevando los elementos sociomusicales que marcan los tiempos de las festividades en los valles de Arica (Díaz et al. 2013).

\section{LA CRUZ EN LOS ANDES}

La literatura sobre la fiesta de la Cruz posee reconocida trayectoria en los estudios mesoamericanos (Solís 2004; Gómez 2012) y en los Andes (González 1992a, 1992b; Molinié 1997; Kuon 2007; Ramírez 2009; Millones \& Tomoeda 2011), con una variedad de enfoques y reportes etnográficos acerca del simbolismo, las peregrinaciones y su organización. En Chile existen tratativas sobre celebraciones en varias regiones campesinas de la zona central (Sáez 2005; Uribe 2008). Para el caso del norte chileno, son fundamentales los aportes de Van Kessel (2006) para acercarse a lógicas aymaras y litúrgicas en la celebración de la Cruz de Mayo, como, a su vez, las valiosas contribuciones desarrolladas por Barrientos (1984) para el valle de Azapa con importantes registros de partituras sobre cánticos a la cruz y las referencias de Dannemann y Quevedo (1994-1995); además del 
culto los de afrodescendientes en los territorios, junto a sus linajes y cruces (Díaz et al. 2020). Adicionalmente, existen antecedentes sobre el rol que desempeñan la conformación de agrupaciones musicales de la zona norte (bandas de bronces, bandas de lakas, grupos de cumbia), el despliegue de manifestaciones sonoras y la utilización de determinados instrumentos musicales para el desarrollo de un sinnúmero de festividades. Estos roles se vinculan con un sistema de cargos religiosos como alféreces, mayordomos o cabecillas, en los poblados precordilleranos o valles de las regiones de Arica y Parinacota, y Tarapacá (Mamani 1988-1989; Díaz 2009).

$\mathrm{Si}$ bien existen algunas diferencias en sus manifestaciones, sabemos que, en general, durante la celebración de la Cruz de Mayo se siguen tópicos rituales propios de las fiestas patronales, constituyendo la dimensión sonora un vector para el desarrollo de las fases que abarca la festividad. Así, con la presencia de bandas de bronces, ${ }^{1}$ lakitas, orquestas de cumbia y cantores, se reestructura la celebración entre el campo y la ciudad, transformando el mapa y el calendario sonoro del norte chileno al utilizar diversos medios para intensificar la comunicación, con marcadores asignados por los músicos, pasantes (alféreces o mayordomos) o comuneros de los valles nortinos como Lluta, Azapa y Codpa. Las etnografías que sintetizan las fases rituales y sus correspondientes sonoridades de bandas de bronces en contextos festivos, se presentan a continuación (Tambiah 1985; Díaz et al. 2013).

\section{Cruz de Mayo en Lluta}

Al norte de la ciudad de Arica se encuentra el valle de Lluta, lugar con amplios sectores destinados a la agricultura de maíces y con una alta presencia de población indígena, sobre todo en los sectores altos. En dicho lugar, la Cruz enclavada en las laderas de los cerros es celebrada en las cercanías de los campos de cultivos o en caseríos a lo largo de todo el valle, teniendo correspondencia con las áreas de cultivos de familias indígenas o afrodescendientes, con un repertorio amplio de festejos para carnavales y cruces. Para el caso de este estudio, se trabajó en el área de Chapisca, que corresponde a un caserío ubicado a $55 \mathrm{~km}$ de Arica (fig. 1). Su población se reduce a un pequeño número de familias que poseen terrenos agrícolas y que suelen retornar para los períodos de siembra y cosecha, ya que el resto del año residen en la ciudad o en sectores costeros. Durante los primeros días del mes de mayo, la comunidad se congrega para celebrar la fiesta de la Cruz. A diferencia de lo que ocurre en la mayoría de los pueblos andinos, en este lugar no existe la advocación a un santo patrono para conmemorar o festejar.

De acuerdo con los reportes realizados por Manuel Mamani entre 2005 y 2015, la comunidad expone que la celebración de la Cruz data aproximadamente de la década de 1960, momento en que el matrimonio compuesto por Martín Mamani y Herminia Zárate trajo la Cruz al sector de Chapisca. Se inauguró asíla tradición de honrar la Cruz, la que, a decir de los devotos, concede milagros y favores. Por ello deben festejarla y entregarle ofrendas, de modo que provea de abundante agua y asegure una buena producción agrícola.

La festividad puede realizarse durante varias fechas o fines de semana a lo largo del mes de mayo, de acuerdo con el programa que establezcan los alféreces, mayordomos o pasantes, cargos religiosos que reciben estas denominaciones. Para sintetizar, describiremos la fiesta con sus diferentes momentos en Chapisca: el día 1 de mayo, los alféreces, junto a su familia más cercana, bajaron una de las cruces desde su lugar original en la cima de un cerro cercano del caserío, para trasladarla luego hasta una casa en Arica. En este caso, los alféreces se encargaron no solo de costear la festividad, sino también de realizar los cuidados de la cruz. En pueblos precordilleranos, como Socoroma, cada cruz posee una pareja de mayordomos que se encargan de su cuidado y mantención, además de preocuparse de atender a los fieles devotos que la acompañan durante toda la celebración. Hay poblados en los que, al bajar la cruz durante la Semana Santa, la dejan en custodia en la capilla del poblado hasta el momento de la celebración en el mes de mayo, dependiendo siempre de la organización de los pasantes.

En Chapisca, la fiesta comienza en la víspera del 13 de mayo, en este caso, la tarde del sábado 12. Cerca del mediodía, el alférez y parte de su familia trasladaron la cruz desde Arica hasta Lluta para dejarla en la casa de uno de los tíos del alférez, quien a su vez está emparentado con los fundadores del caserío. Debemos consignar que en Chapisca no existe capilla católica y se rinde tributo a dos cruces: una principal denominada "El Carmen" (la cual fue llevada a la ciudad), y una cruz menor llamada por los pobladores "San Martín". Ambas fueron ataviadas y "vestidas" con una tela blanca y adornadas con flores plásticas blancas y naranjas. En la vivienda 

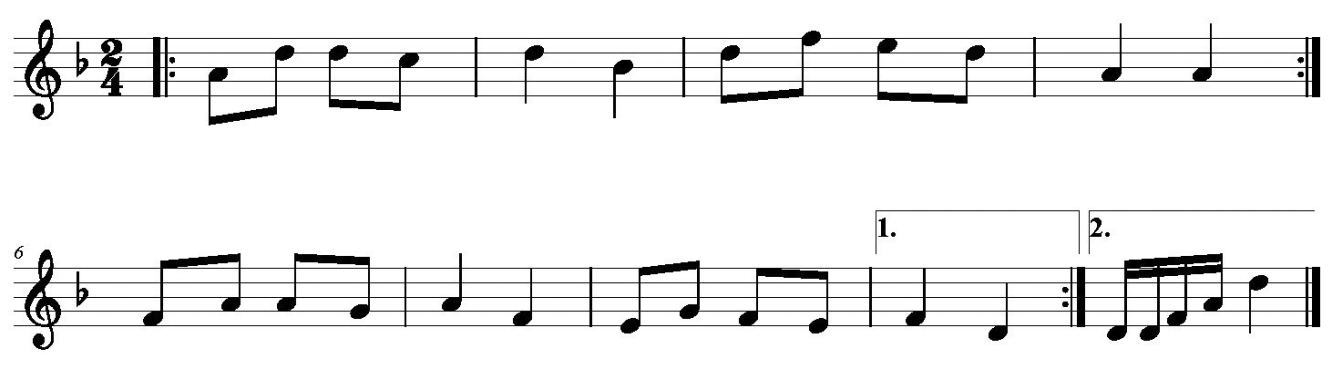

Figura 2. Melodía ejecutada por banda de bronces durante la procesión. Figure 2. Melody performed by brass band during the procession.

señalada se desarrollaron la mayoría de las actividades de la celebración, como también la decoración de la casa y la preparación de alimentos. La festividad se inició cerca de las siete de la tarde, cuando se produjo el arribo de la banda de bronces a las afueras de Chapisca y la gente salió con la Cruz adornada a recibir a los músicos. ${ }^{2}$ Los músicos participan al ser contratados por algún miembro de la comunidad o familiar del pasante, quien recibe la denominación de "cabecilla de banda". Las personas que ostentan este cargo deben aportar voluntariamente con la música para la fiesta y costear todos los gastos que esto implica. Se trata de un compromiso adquirido un año antes, cuando el nuevo alférez asume su cargo. La banda de bronces estaba conformada por una agrupación de residentes andinos en Arica. ${ }^{3}$ Si bien muchas de estas bandas poseen nombre, en algunas ocasiones se reúnen diferentes músicos de otras agrupaciones o independientes para tocar exclusivamente en alguna festividad, generando agrupaciones ad hoc, como ocurrió en este caso. Esta vez, 10 varones, jóvenes y adultos, conformaban la agrupación, distribuidos en un bombo, una caja, platillos, cuatro trompetas y tres tubas.

$\mathrm{Al}$ atardecer se realizó el recibimiento a los asistentes. ${ }^{4}$ Al llegar, las personas se dirigieron a la residencia del antiguo vecino donde permanecían las dos cruces. Ambas fueron ubicadas sobre un aguayo tradicional que contenía hojas de coca, incienso, copal y flores. De fondo, se colocó un manto blanco en la pared y, frente a las flores, un candelabro con velas encendidas. Al llegar a la casa, saludaron y felicitaron a la pareja de alféreces con abrazos y luego se ubicaron frente a la Cruz, persignándose al saludarla y, vela en mano, alzaron rogativas y peticiones de prosperidad y bendición. Posteriormente, encendieron las velas en el candelabro, a la par que la madre del alférez echaba copal a las brasas y sahumaba alrededor de la Cruz y los visitantes.

Mientras parte de la familia del alférez preparaba la comida, la banda de bronces saludó a la Cruz con una melodía andina religiosa (fig. 2), después de lo cual los pasantes invitaron a los asistentes a iniciar inmediatamente la procesión por el caserío. Los participantes no superaban las 30 personas, incluyendo a alféreces y músicos, la mayoría provenientes de Arica o de otras zonas del valle. El alférez sacó la Cruz principal de la casa y la ubicó en medio del camino. Con ayuda de algunos miembros de la comunidad se preparó para la procesión, cargando en su espalda un aguayo en el cual portaba los elementos rituales que utilizaría luego en la celebración: hojas de coca y licor. El aguayo es un indicador del cargo que ostenta el pasante. Luego, cada uno de los alféreces tomó una cruz -el varón la Cruz principal; la mujer la Cruz menor-, y la madre del alférez encendió incienso y lo esparció, lo mismo que el copal, durante toda la procesión (fig. 3). El resto de la comunidad y la banda los siguieron, amenizando con su melodía. Dichas melodías suelen ser ejecutadas en honor a una imagen religiosa, sea dentro de una iglesia o en las procesiones que se realizan a los santos patronos de los pueblos andinos. La melodía, de estructura binaria, estaba en ritmo binario de $2 / 4$, en tonalidad menor (re menor para la banda de bronces). ${ }^{5}$ Solo después de que la banda entonó esta pieza, se inició propiamente la procesión al ritmo de la música.

Durante el trayecto, la banda siguió con su interpretación hasta que los alféreces se detuvieron y apoyaron las cruces en un determinado lugar. Luego, 


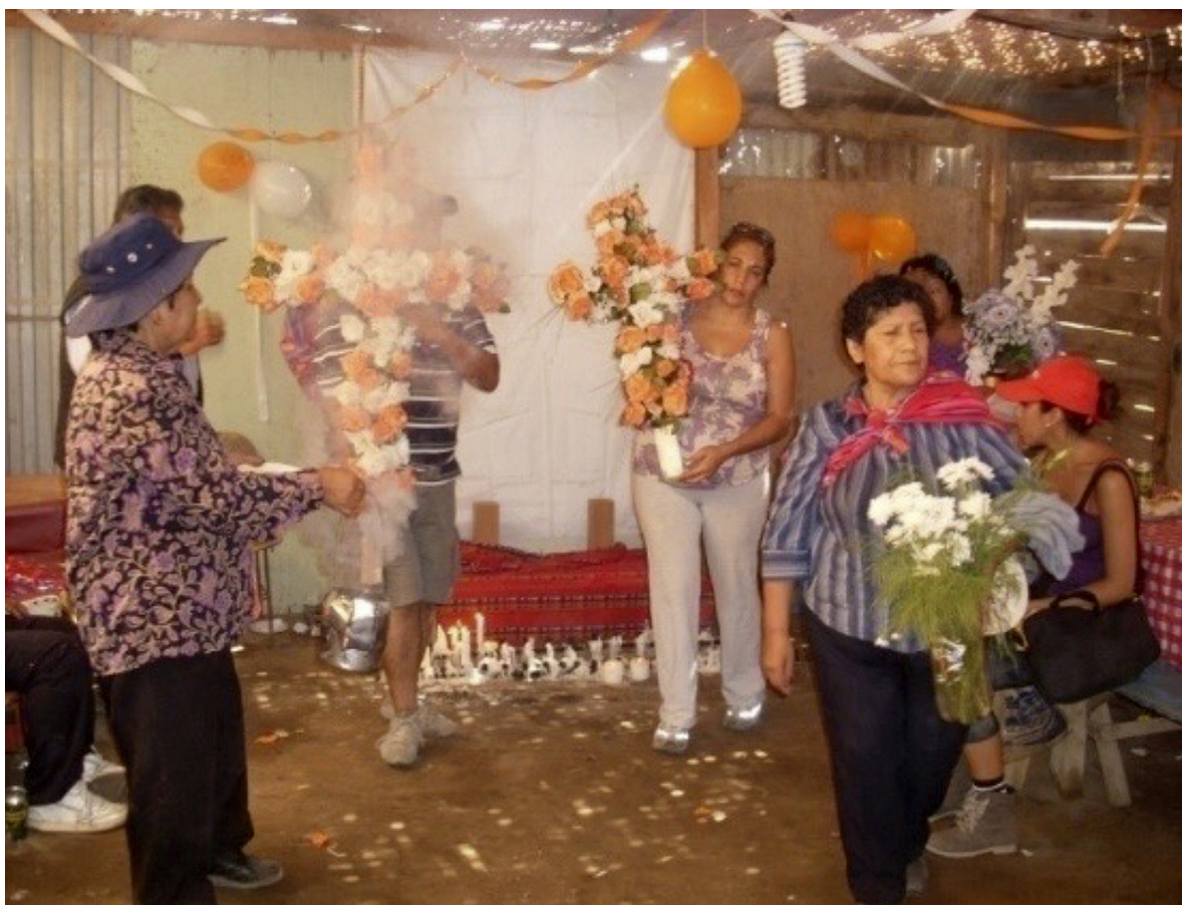

Figura 3. Alféreces sacan las cruces en procesión desde la casa en Chapisca. Figure 3. Standard-bearers take the crosses in procession from the house in Chapisca.

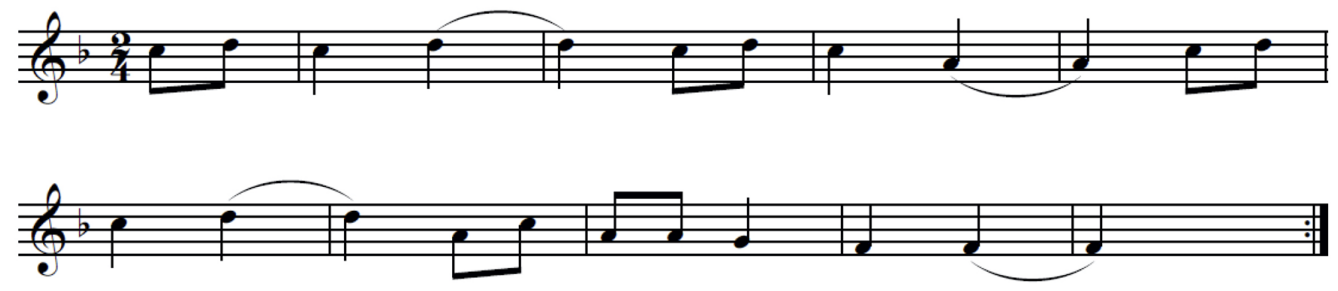

Figura 4. Melodía ejecutada por la banda de bronces mientras la comunidad saluda a la Cruz. Figure 4. Melody performed by the brass band while the community salutes the Cross.

el alférez descargó el aguayo y lo extendió en el suelo al tiempo que la banda dejó de tocar. Durante el silencio, los familiares alistaron y acomodaron los elementos rituales necesarios para chaltar (esparcir licor) y pautar (esparcir hojas de coca). Las cruces se apoyaron sobre el aguayo, agregándose a la mesa ritual botellas de vino, aguardiente y hojas de coca puestas alrededor. Durante la ceremonia de pautar y chaltar, la alférez tomó el copal y comenzó a desplegarlo en un brasero para que saliera humo, sahumando así el sitio en torno a la Cruz. El resto de la comunidad se ubicó alrededor, en silencio, esperando su turno para rendir culto.

Los alféreces pasaron a chaltar y pautar la Cruz mientras pedían por el bienestar de la comunidad. En ese instante, la banda de bronces interpretó una nueva melodía que envolvió el ambiente, intensificando el sentido solemne de la ceremonia (fig. 4). Se trataba de música religiosa andina que suele ser ejecutada en los pueblos andinos en honor a una imagen religiosa dentro de una iglesia. La melodía estaba en ritmo binario de 

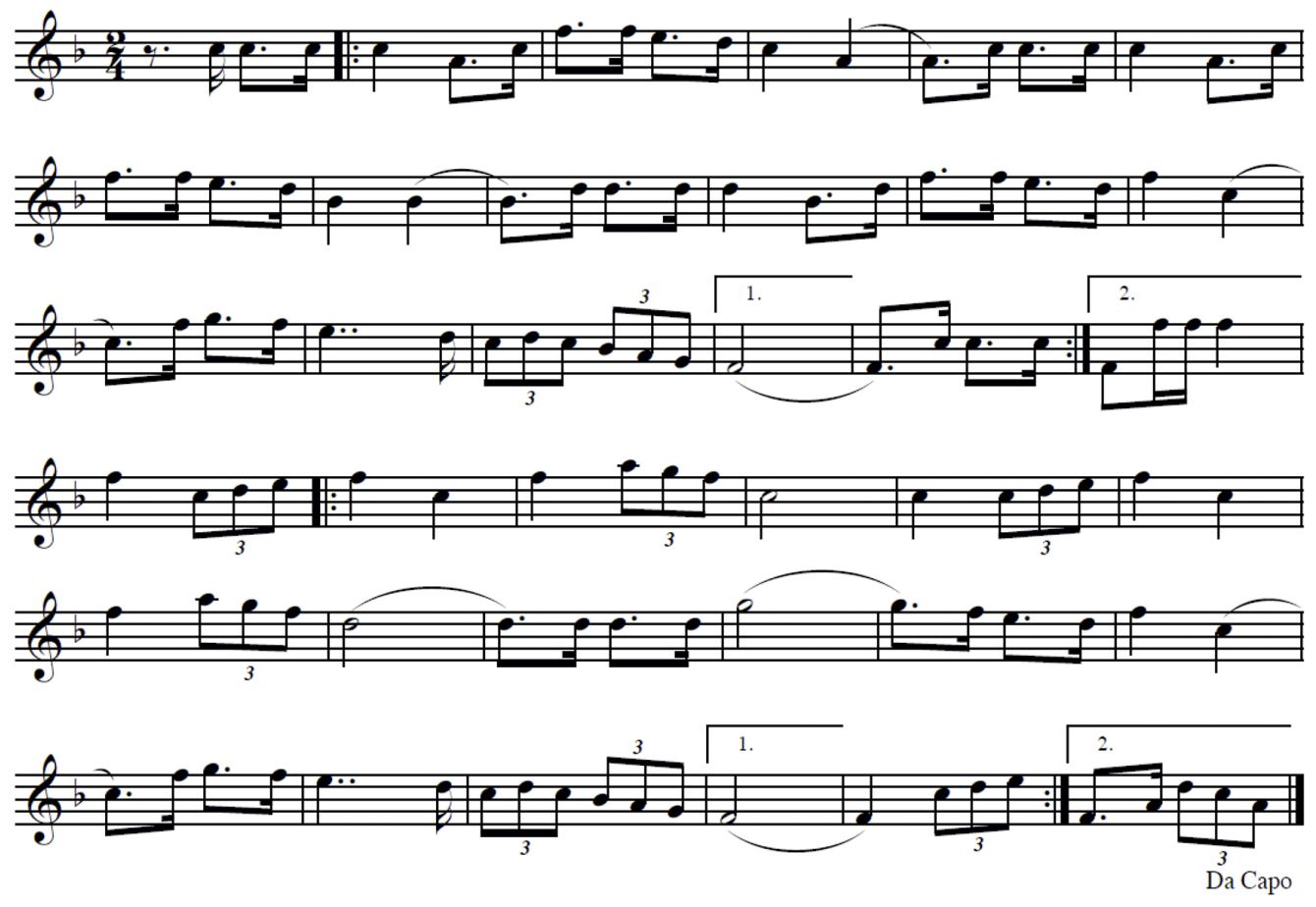

Figura 5. Melodía ejecutada por la banda de bronces para culminar la ceremonia. Figure 5. Melody performed by the brass band to conclude the ceremony.

2/4, de tonalidad pentafónica, y la estructura era simple y binaria, al igual que la pieza ejecutada anteriormente.

Luego, cada uno de los asistentes realizó el mismo ritual en honor a la Cruz. Una vez que todos lo hicieron, la banda interpretó una marcha (fig. 5), indicando con ello el final de la actividad, después de lo cual continuó el traslado de las cruces.

En los pueblos andinos es una tradición que las bandas interpreten marchas al iniciar y terminar algún acto de carácter religioso o social (Díaz 2009), y para acompañar a los personajes rituales, como el alférez o mayordomo. Esta melodía también tiene un ritmo binario de $2 / 4$, de tonalidad mayor (fa mayor para la banda de bronces) y una estructura cuaternaria. ${ }^{7}$

Al oír la música, los alféreces se aprestaron de inmediato a tomar las cruces para retornar a la casa. Luego de esta señal melódica, la comunidad también retomó la procesión, mientras algunos de sus miembros reventaban petardos en un ambiente de pólvora y estruendos. Una vez en la casa, los alféreces ubicaron las cruces en un altar levantado para la ocasión, acompañados en todo momento por la banda. Se encendieron velas en honor a la Cruz, dando término así a esta fase ritual. El momento fue seguido por una enérgica celebración con música y baile comunitario producto de la irrupción de dianas o fanfarrias, continuadas por la interpretación de una cueca nortina (fig. 6), la que fue bailada por la pareja de alféreces junto con los "cabecillas de banda" y vecinos del sector. Es importante señalar que la cueca también es un género melódico de tipo social, que se incorporó en el área andina durante la época de la chilenización y suele ser interpretada y bailada en actos públicos y religiosos (Díaz 2009). En este caso, las primeras cuecas ejecutadas fueron destinadas exclusivamente para que bailaran quienes poseen o poseyeron recientemente algún cargo en la festividad. Esta melodía poseía un ritmo binario compuesto de $6 / 8$, de tonalidad menor (re menor para la banda de bronces) y con una estructura binaria. ${ }^{8}$

Terminadas las cuecas, la banda interpretó algunos huaynos (fig. 7), uniéndose al baile otros miembros de la 


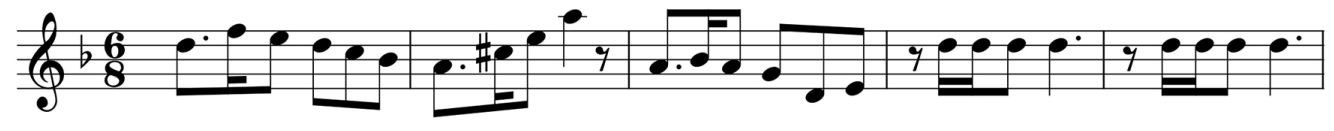

$\$$
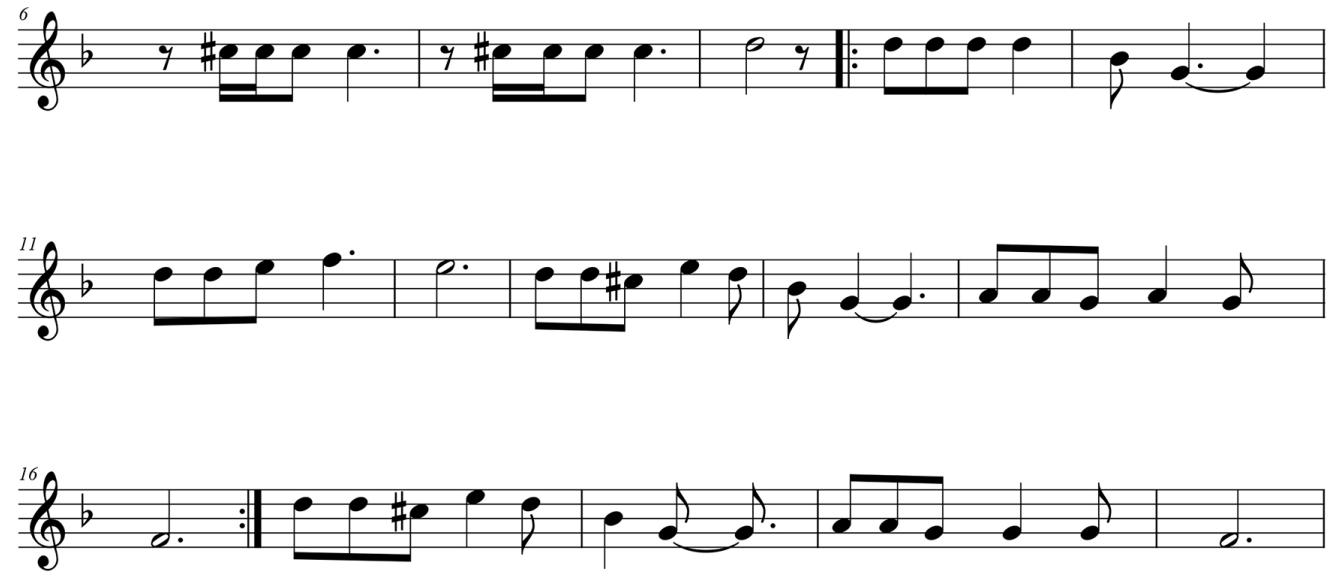

Finalizar

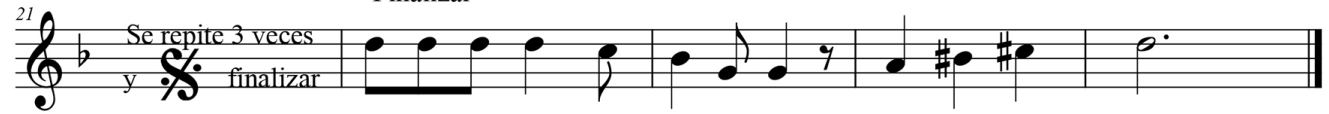

Figura 6. Cueca nortina ejecutada por la banda de bronces. Figure 6. Northern cueca performed by the brass band.

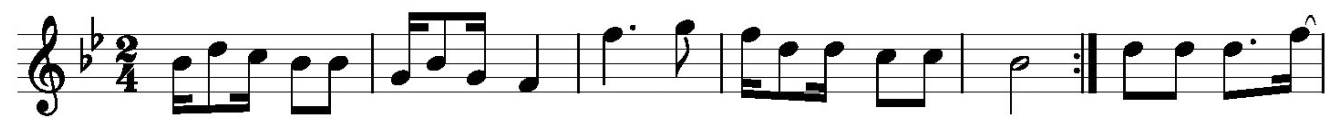

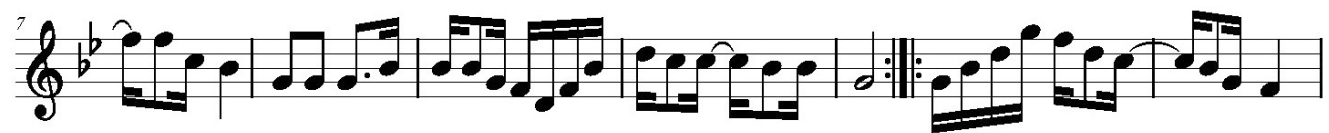

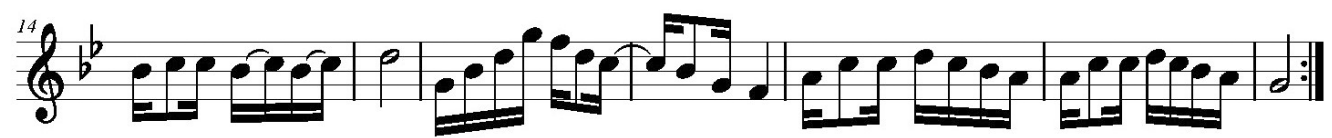

Figura 7. Huayno ejecutado por la banda de bronces. Figure 7. Huayno performed by the brass band. 
comunidad y visitantes. El huayno, o wayñu en aymara, es un género musical andino con su propio uso social y ritual, que suele ser danzado en diversas ceremonias, especialmente en las fiestas patronales de los pueblos. En esta ocasión, su melodía estaba en ritmo binario de $2 / 4$, de tonalidad menor (sol menor para la banda de bronces) y de estructura cuaternaria. ${ }^{9}$

Una orquesta de música tropical andina aguardaba su turno a un costado de la residencia. Tal como la banda de bronces, se trataba de una agrupación de residentes indígenas de la ciudad de Arica, quienes fueron contactados con un año de antelación para acompañar a los alféreces. Esta banda estaba integrada por cinco varones adultos, quienes portaban guitarras, teclados, bajo y batería eléctrica. Una vez que la banda de bronces interpretó la última cueca, el vocalista de la orquesta invitó a bailar un huayno a los "cabecillas de banda”, extendiéndose la música y el baile durante media hora más.

Los alféreces, acompañados de sus parientes y donantes, ubicaron en el centro de la casa una mesa ritual cubierta con un aguayo, sobre el cual depositaron bebidas, hojas de coca y una bandeja con encintados grabados con la fecha de la fiesta y los nombres de los alféreces. Los pasantes fueron los encargados de poner la banda tricolor a los alféreces entrantes. Además, hicieron pasar a la mesa a los "cabecillas de banda" y a otros miembros que habían cooperado con la fiesta para entregarles los encintados como reconocimiento al aporte realizado. La banda de bronces entonó una diana cada vez que alguien recibió el distintivo. Luego, distintas familias de Chapisca hicieron donaciones voluntarias, como alimentos (papas, choclos, cebollas, arroz, azúcar) y bebidas (cerveza), ubicándolas junto a la mesa que acompañaba la ceremonia. Otros prendieron billetes en la solapa de los alféreces. En este caso, también, el alférez solicitó a la banda una diana en señal de gratitud.

El rol de la banda de bronces fue clave en el encintado y la celebración que se realizó durante aquella primera noche de vísperas en Chapisca, pues sus melodías fueron señalando las pautas de acción y su sentido ritual. Esta experticia músico-ritual es un prerrequisito que deben cumplir todas las agrupaciones participantes y es un supuesto conocido por los "cabecillas" a la hora de contratar sus servicios.

Una vez que terminó la ceremonia, se dio paso al baile ofrecido por la orquesta que interpretó cumbias andinas hasta altas horas de la madrugada. Es intere- sante señalar que la práctica de contratar orquestas electrónicas parece ser reciente. El alférez recuerda que antiguamente existían pocas agrupaciones musicales de este tipo y la principal alternativa musical provenía de las bandas de lakitas. Esto debido al deseo de mantener las costumbres o bien a la escasez de generadores eléctricos. A decir de los comuneros, siempre debía presentarse un grupo musical para acompañar a los pasantes de la festividad, independiente de sus características sonoras, con o sin contrato.

$\mathrm{Al}$ amanecer del siguiente día, el silencio en el valle fue interrumpido por "el alba", saludo musical de la banda a la Cruz. A la actividad asistieron las personas con algún cargo comunitario, incorporándose paulatinamente los participantes de la festividad a medida que oían los sonidos de los bronces. Este momento no se extendió por más de media hora, tras lo cual la familia del alférez ofreció un tradicional plato de kalapurka.

Durante la mañana, después de realizar algunas oraciones, los pasantes y su parentela prepararon las cruces para llevarlas hasta la cima del cerro. Sabemos que, en otros sectores del valle de Lluta, como también en Copaquilla o Socoroma, mientras se preparan las cruces durante el día principal de la fiesta, las orquestas, los grupos tradicionales y los cantores locales elevan una serie de coplas en honor a la Santa Cruz, denominadas "cuculís". En los estribillos los acompañan los mayordomos y comuneros. ${ }^{10}$ En esta ocasión, en Chapisca, el alférez se puso el aguayo y tomó la Cruz principal, su pareja hizo lo propio con la Cruz menor, mientras su madre esparcía incienso permanentemente y la banda interpretaba una marcha, ritmando todo el trayecto de la procesión hasta llegar a los pies del cerro. El esquema musical de la marcha representada en la partitura (fig. 8), refleja de manera clara el grado de solemnidad que revistió esta práctica ritual durante el traslado de las cruces.

Los pasantes con las cruces, la banda de bronces y la comunidad subieron al cerro, en cuya cima se ubicó un altar que adornaron con flores, lugar donde se instalan las cruces. Frente al altar, desplegaron un aguayo para una mesa ritual. En ese momento, se dio paso a la adoración a la Cruz, instante en que la pareja de alféreces y cabecilla de la fiesta realizaron el chaltar y pautar de las cruces, mientras elevaban sus rogativas. Este acto fue replicado por el resto de los asistentes, al tiempo que la banda entonaba melodías de adoración o "benditos" para acompañar la actividad. 


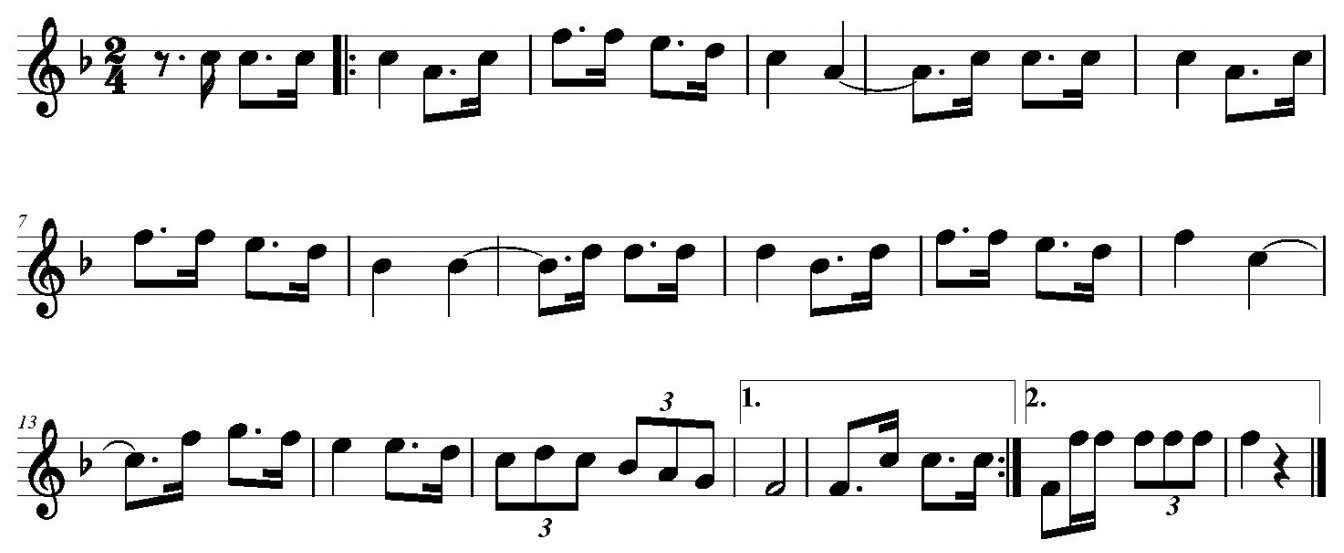

Figura 8. Marcha ejecutada por la banda de bronces durante la procesión al cerro. Figure 8. March performed by the brass band during the procession to the hill.

Este acto fue realizado con solemnidad, contemplando rogativas andinas dedicadas a la Pachamama. Al finalizar, el alférez se dirigió a la comunidad para agradecer a los presentes por acompañarlos a "pasar la fiesta". La actividad culminó con la entrega oficial de las cruces que habían custodiado y celebrado durante la festividad. Apenas terminó de hablar, los cabecillas ordenaron a la banda que entonara una diana y luego una marcha, para celebrar la labor realizada por los pasantes, mientras la comunidad aplaudía como muestra de agradecimiento. En ese momento, una joven pareja anunció su decisión de asumir el cargo de alféreces para el año siguiente. La banda de bronces celebró tal decisión con una diana, huaynos y cumbias. Posteriormente, los nuevos alféreces se ubicaron junto al altar y cada uno levantó brevemente una de las cruces. La ocasión se aprovechó también para repartir bebidas (sobre todo cervezas) con las que brindaron y compartieron. Las cruces quedaron instaladas en el lugar hasta el año siguiente, resguardando todo el sector y a la comunidad de Chapisca.

Finalmente, toda la comunidad emprendió el regreso. Ya en el caserío, la banda reinició la interpretación musical de marchas y huaynos hasta llegar a la casa de los alféreces. Una vez en su interior, los pasantes invitaron a almorzar a los visitantes para agradecer el apoyo y la presencia en las ceremonias. En este ambiente de cordialidad se dio término a la festividad. Luego, los asistentes retornaron a Arica, revitalizados por el encuentro celebrado en honor a la Cruz de Chapisca.

\section{Cruz de Mayo en Codpa}

La Cruz de Mayo es también una de las fiestas que se celebran en el valle de Codpa, con participación familiar, tal como se evidencia en el caso de Markirave, que revisaremos a continuación. Este caserío se encuentra ubicado a $2 \mathrm{~km}$ del poblado colonial de Codpa. Lo conforman cuatro viviendas y actualmente integran su comunidad las familias Montealegre, Tapia, Condori y Manzanares (fig. 9). Solo algunos miembros de estas familias residen todo el año en el sector. Se trata de personas adultas que se dedican al trabajo en sus chacras y sus descendientes viven en Arica u otras ciudades del país. La celebración a la Cruz se realiza en este lugar cada 2 de mayo, con la asistencia de la banda de bronces.

Muy temprano, alrededor de las 5.30 horas, diversos representantes de las familias iniciaron la fiesta en Markirave junto a la banda de bronces, subiendo hasta el calvario ubicado en la cima del cerro principal para traer de allí las cruces. Esta actividad la suelen desarrollar únicamente los varones; las mujeres, en tanto, preparan la comida. Ya en la cima del cerro cercano al caserío se dispusieron a retirar las ocho cruces pertenecientes al territorio de Markirave, limpiando sus emplazamientos y acompañándose de melodías de alabanzas a la Cruz. A decir de los comuneros, la gran cantidad de cruces en dicho sector obedece a que, antiguamente, la fiesta de todo el valle era celebrada en Markirave, acudiendo comunidades provenientes de Chitita, Guatanave, 


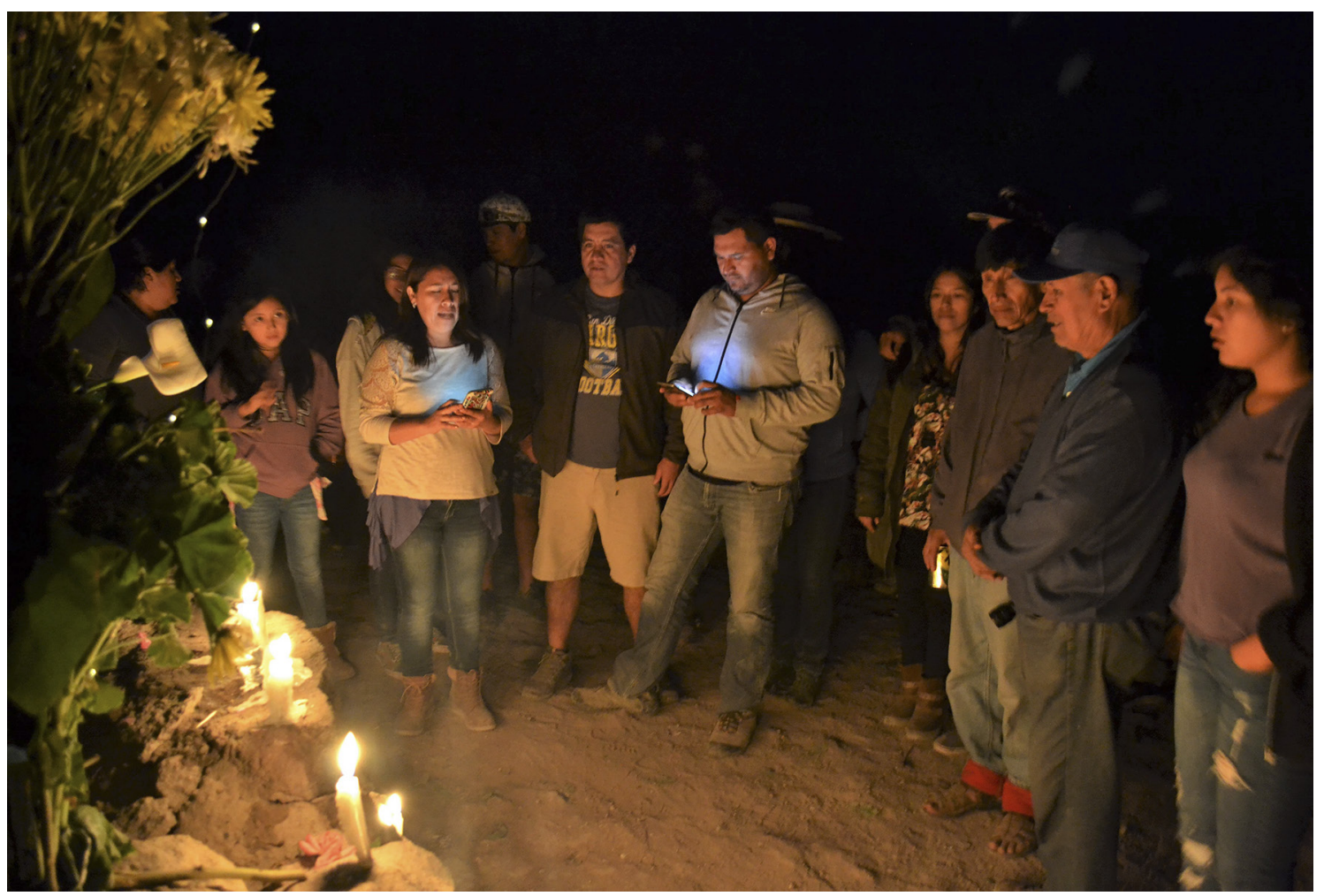

Figura 9. Familia Montealegre cantando a la Cruz. Figure 9. Montealegre family singing to the Cross.

Poroma, Codpa, Ofragía y Cerro Blanco. Cada una de estas comunidades poseía una cruz ubicada en el calvario, además de la propia de la capilla de Markirave y la Cruz de la Piedra. Esta antigua tradición fue perdiéndose al celebrar a la Cruz en diferentes áreas a lo largo del valle.

Tras una serie de libaciones con licores a los altares de las cruces y acompañados de melodías de marchas, algunos de los asistentes tomaron una cruz en sus brazos y comenzaron a salir uno a uno del calvario. Durante el descenso, la banda musicalizó el trayecto hasta la capilla con una marcha.

$\mathrm{Al}$ son de una marcha interpretada por la banda, los cargadores ingresaron con las cruces a la capilla, ubicándolas en la parte frontal para su veneración. El sonido de los bronces entonado por la banda dentro de la capilla era intenso y estridente. Al salir del templo interpretaron el himno nacional de Chile mientras izaban la bandera. Después de saludar a los encargados de la festividad, la banda visitó a los organizadores de la celebración, quienes los esperaban con kalapurka, un plato típico que se come en los pueblos andinos durante las fiestas patronales. En dicho lugar, la banda interpretó huaynos, congregando a los comuneros y animando el baile de los asistentes durante aquel día. Por la tarde, un grupo de mujeres acudió al templo para "vestir" las cruces con refinadas telas.

El 3 de mayo, las familias de Markirave y la banda de bronces se reunieron en la capilla para participar en la liturgia y la procesión. Durante la procesión, entre las oraciones se musicalizó el desplazamiento con las sonoridades de los bronces al ritmo de marchas y alabanzas, mientras la feligresía acompañaba a las personas que llevaban las cruces. En lo particular, en las oportunidades en las cuales se ha participado, los jóvenes de la familia Montealegre cargaron las dos cruces principales, las más grandes, ataviadas o "vestidas" -como suele llamarse- el día anterior con un llamativo satín azul, cintas de colores, espejuelos y otros adornos. Al costado de la cruz principal se ubicó la Cruz de la Piedra, la única que estaba vestida por un visillo amarillo y que era cargada por un joven de la familia Tapia. Al otro costado, un niño de la familia Montealegre llevaba una de las cuatro cruces 

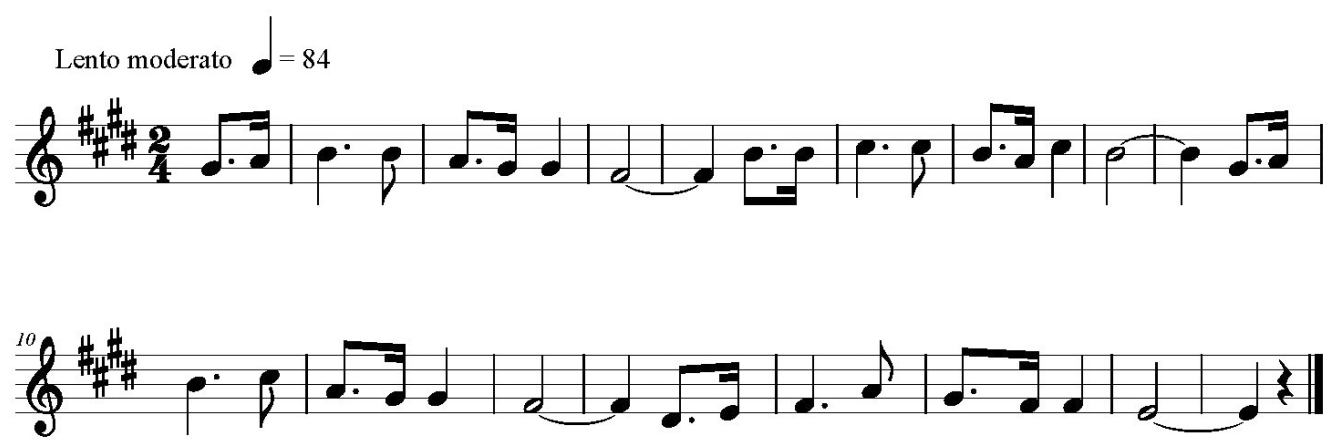

Figura 10. Melodía de los cantos (alabanzas) interpretados en honor a la Cruz en Markirave. Figure 10. Melody of the songs (praises) performed in honor of the Markirave Cross.

menores que se ubican en las esquinas del calvario y están vestidas con un satín azul. Las marchas hacían eco en el estrecho valle, marcando el avance de los devotos que caminaban con paso firme y seguro.

Una vez que arribaron a la casa de la familia Montealegre, la primera estación del caserío, los asistentes y músicos se congregaron frente a la vivienda. Por su parte, adultos, niños y niñas que cargaban las cruces del calvario -dos principales y cuatro pequeñas- y la Cruz de la Piedra se situaron de espaldas a la casa, con las cruces sobre una manta de color gris. Las cruces del calvario quedaron en el centro, a la derecha la Cruz de la Piedra y detrás de ella una de las cruces "esquineras". Las tres restantes, transportadas por niños, se ubicaron delante de las cruces mayores. Después de que los músicos dejaron de tocar, el diácono inició la oración con la señal de la cruz y elevó una súplica por el perdón de los pecados de los presentes y por el bienestar de las familias del caserío. A continuación, invitó a rezar el padrenuestro con todos los fieles tomados de las manos y a cantar alabando a la Cruz.

Según don Francisco Zenis, antiguo codpeño, el cargo oficial de cantor no existe en Markirave desde hace ya varios años. Por ello, otras personas asumen esta función provisoriamente. Las letras de las canciones son registradas en cuadernos que se guardan en el templo y son interpretadas por un/a eventual cantor/a, quien lleva la primera voz en la estrofa principal y el resto de los asistentes repite el coro o estribillo. Este patrón musical se reitera en la festividad. Últimamente, son cantoras quienes llevan el corpus de melodías para las cruces en
Markirave. El detalle del cántico es el siguiente:

La Cruz es la principal [cantora] que debemos de adorar, todos los fieles cristianos digamos por la señal.
Alabado sea el Santísimo [coro]
Sacramento del altar
y la Virgen concebida
sin pecado original.

\begin{abstract}
Santísima Cruz de Mayo [cantora] que estás en el monte Calvario, donde está nuestro Señor a quienes sus manos clavaron.
\end{abstract}
Alabado sea el Santísimo [coro]
Sacramento del altar
y la Virgen concebida
sin pecado original.

El canto y las melodías procesionales en Markirave (fig. 10) corresponden a una de las alabanzas típicas interpretadas en honor a la Cruz en diversos poblados andinos del norte de Chile. Esta práctica consiste en que el cantor tradicional -que, en ocasiones, también es un guitarrero- interpreta una estrofa y luego los asistentes repiten el coro con la misma melodía. Esta alabanza se suele ejecutar a lo largo de toda la festividad, variando únicamente las estrofas que entona el cantor. Además, 
pueden existir diferencias en las entonaciones o los acentos que cada intérprete le asigna en su lírica. El giro melódico de esta pieza se inscribe en mi mayor, en ritmo binario y posee un esquema también binario. ${ }^{11}$

Continuando con la fiesta, a los pocos minutos la procesión arribó hasta la segunda parada: la casa de la familia Tapia, donde se reiteró el rito. El diácono preguntó si sabían quiénes habían iniciado la fiesta de la Cruz, ante lo cual una mujer respondió tímidamente "nuestros bisabuelos". Acto seguido, entre varias oraciones, la cantora entró con los siguientes versos:

\author{
Asómate a la ventana [cantora] \\ y verás lo que no has visto, \\ y verás a Magdalena \\ limpiando los pies de Cristo. \\ Alabado sea el Santísimo [coro] \\ Sacramento del altar \\ y la Virgen concebida \\ sin pecado original.
Al alzar la vista al cielo [cantora]
y verás al niño Dios,
vestido de raso blanco
que nació para la Cruz.

\section{Alabado sea el Santísimo [coro] \\ Sacramento del altar \\ y la Virgen concebida \\ sin pecado original.}

De esta forma, el canto no solo permite recrear el sentido que poseen las distintas estaciones que la comunidad va realizando, sino que, al ser interpretado por la banda de bronces como una alabanza, es desplegado también como una forma de loa colectiva, evidenciando la importancia de la música durante la festividad.

Señor Mío, Jesucristo [cantora]

échanos tu bendición,

así como se la echaste

en la Cruz al buen ladrón.

Alabado sea el Santísimo [coro]

Sacramento del altar

y la Virgen concebida

sin pecado original.

Sangre fresca, sangre de Cristo [cantora] derramada en la Cruz, la ofreció al eterno Padre para nuestra salvación.

Alabado sea el Santísimo [coro]

Sacramento del altar

y la Virgen concebida

sin pecado original.

Esta doy por despedida [cantora]

la que dio Cristo en Belén,

distinguiendo a tres personas:

Jesús, María y José.

Alabado sea el Santísimo [coro]

Sacramento del altar

y la Virgen concebida

sin pecado original.

Después de los actos litúrgicos y los festejos realizados durante el día, por la tarde se programa la "subida de las cruces", las que, en algunas ocasiones, son llevadas el día 4 de mayo a los cerros. En casa de los celebrantes se reúnen familiares y amigos. Algunos acuden a limpiar la capilla desde donde saldrán las cruces, mientras un grupo de varones va al río a cortar ramas para adornarlas.

Después de que el toque de la campana del templo anunció el traslado de las cruces, se congregaron los peregrinos y comenzaron a sacar una cruz que se ubica regularmente en una gran piedra situada en la plaza frente a la capilla, al costado del camino; cruz a cargo de la familia Tapia. Posteriormente, los comuneros hombres y niños ayudaron a cargar las cruces, conformándose una procesión hacia el calvario siguiendo el ritmo de marchas.

Primero salieron con las cruces grandes, seguidos por los cargadores de cruces pequeñas, $y$, entre estas, una pequeña llamada "limosnera". Si bien la banda interpretó una marcha inicial, luego dejó de tocar y acompañó en silencio. Después de caminar aproximadamente 100 metros por el serpenteado camino, la procesión llegó a los pies del cerro donde se ubicaba el calvario. Todos se detuvieron, bajaron las cruces y esperaron a la banda y al encargado de la celebración, quien encendió un petardo y una bengala, cuyo sonido retumbó en todo el valle. Luego del estruendo, la banda entonó la melodía "Alabado sea el Santísimo". Todos los músicos se ubicaron frente a la Cruz, al tiempo que quienes portaban cruces 
se giraron para observar reverencialmente el calvario. $\mathrm{Al}$ terminar la alabanza, uno de los abuelos de la comarca dio la señal para subir el cerro. Uno a uno, comenzando por quienes llevaban las cruces más grandes y luego las más pequeñas, subieron por un sendero pedregoso y escarpado. En ese instante, la banda interpretó nuevamente una marcha que se extendió hasta que todos los cargadores iniciaron el trayecto.

Los cargadores arribaron a una planicie ubicada antes de la última pendiente que desemboca en el calvario. $\mathrm{Al}$ detenerse, esperaron a los músicos para que los compases de las marchas siguieran marcando el desplazamiento hacia el calvario. Ya en la cima del cerro, las cruces fueron ubicadas a los pies del calvario, las más grandes en el centro y el resto alrededor, la mayoría orientadas hacia el pueblo de Guatanave. Un grupo de mujeres de la comunidad llevaron del valle un manto blanco con encajes -que extendieron cuidadosamente en el suelo, a un costado de las cruces-, flores y ramas. Sobre el manto se desplegó un mantel de color blanco con igual cuidado. Algunas de las participantes tomaron después las cruces grandes y pequeñas y, con la ayuda de otras mujeres y niños, comenzaron a desvestir las cruces de los ropajes usados en la celebración. Esta labor fue acompañada por diversas melodías de alabanzas al llegar la noche.

Luego, comenzaron a vestir las cruces. La tarea de cubrir y adornar las cruces con ramas y flores es un trabajo colectivo que requiere cooperación entre las mujeres. En paralelo, siempre con melodías piadosas que tocaba la banda, los demás participantes compartieron algunas vivencias comunitarias bebiendo vino Pintatani. ${ }^{12}$ Terminado el revestimiento de todas las cruces, los varones procedieron a instalarlas en sus respectivos altares del calvario. El sitio estaba iluminado por velas y la luz de la luna. Mientras esto ocurría, la banda entonaba "Alabado sea el Santísimo". Al finalizar las ceremonias de "subida de las cruces", una cantora se dispuso a cantar:

Buenas noches, Cruz divina, [cantora] buenas noches, Cruz del cielo,

las noches te vengo a dar con mi más profundo anhelo.

\footnotetext{
Alabado sea el Santísimo [coro]

Sacramento del altar

y la Virgen concebida

sin pecado original.

Adoremos esta Cruz [cantora]
}

que es tan lindo madero, que nos ha de acompañar hasta nuestra sepultura.

\author{
Alabado sea el Santísimo [coro] \\ Sacramento del altar \\ y la Virgen concebida \\ sin pecado original.
}

\section{Cuando pases por la Cruz [cantora] te has de quitar el sombrero, donde juntó sus espaldas al [no se entiende] divino cordero.}

\author{
Alabado sea el Santísimo [coro] \\ Sacramento del altar \\ y la Virgen concebida \\ sin pecado original.
}

Esta doy por despedida [cantora] la que dio Cristo en Belén, distinguiendo a tres personas Jesús, María y José.
Alabado sea el Santísimo [Coro]
Sacramento del altar
y la Virgen concebida
sin pecado original.

Al finalizar el canto, la mujer pronunció un "ave María purísima”, que repitió dos veces y que fue replicado por todos los asistentes: "sin pecado concebida". Luego todos se persignaron mientras se pidió que pasaran a pawar ${ }^{13}$ la ropa de las cruces. Los asistentes se dirigieron hacia el lugar donde estaban los hermanos Condori, quienes tenían a sus pies los ropajes de la cruz envueltos en un mantel blanco. Cuidadosamente, los hermanos habían extendido también un pequeño manto al costado de los ropajes, sobre el cual habían colocado mangos, guayabas, membrillos, naranjas y hojas de coca. Se formó una fila frente a los ropajes de las cruces. En algunos casos se tomaron luego las hojas de coca y se vertieron sobre el paño, los abuelos comenzaron a realizar una lectura interpretativa según la forma en que caía la coca, cómo se distribuían las hojas y sus características. Uno de los principales de la comunidad hizo una lectura para responder preguntas de los asistentes sobre su situación amorosa y sobre diversos aspectos del futuro del pueblo; 
todo ello en un clima solemne, al cual se sumaron los músicos para pawar, según la costumbre.

Mientras se desarrollaba esta práctica, se solicitó a la banda que tocara un huayno, a lo que los músicos respondieron al unísono con melodías alegres para conformar una danza entre los asistentes. Se formó una rueda alrededor del calvario, y las personas giraron tomadas de la mano, riendo y bromeando. Fue un momento de algarabía. Tras el jolgorio provocado por los sonidos de huaynos y cumbias, se dio por finalizada la fiesta de la Cruz al ritmo de la cacharpay ${ }^{14}$ entonada por la banda de bronces.

\section{CONSIDERACIONES FINALES}

Las sonoridades son un fenómeno clave para el desarrollo de las festividades de la Cruz de Mayo en los valles de Arica y, tal como se ha constatado, esta celebración las incorpora durante todo el proceso ritual. La indagatoria durante años de trabajo en fiestas nos ha permitido verificar que las cruces honradas obedecen a distintos criterios de organización. Como se ha descrito, tanto en Lluta como en Codpa la celebración está vinculada a determinados sectores agrícolas y con algunas familias o linajes históricos de la zona. De hecho, la función originaria o fundacional de una familia se verifica en Chapisca, donde la comunidad reconoce que la tradición se inició en la década de 1960 debido al ímpetu del matrimonio Mamani Zárate, quienes, al parecer, comenzaron a celebrar la fiesta trayendo la costumbre de sus experiencias en la precordillera andina. Desde entonces, son una familia de referencia para la celebración, formando parte de la memoria festiva que reactualiza cada año dicho acontecimiento fundante. La tradición es mucho más antigua en Markirave, y aunque su origen es difícil de rastrear, este podría corresponder a épocas coloniales tardías asociadas a procesos catequísticos vinculantes a la doctrina de Codpa. Con todo, es un examen histórico que aún debe evaluarse (Díaz et al. 2013).

A diferencia de lo que ocurre en otros lugares del valle, una sola familia se hace responsable de gestionar la festividad en Markirave. La mayoría de los gastos, las labores necesarias para rendir un culto adecuado a las cruces, la música y la ejecución de cantos son responsabilidades de esta familia. Así, el carácter familiar que adquiere la fiesta está dado por el tipo de organización que sustenta la celebración, tal como sucede en el valle de Azapa con las comunidades afrodescendientes y migrantes andinas que ritualizan su linaje en torno a cruces familiares. Ciertamente, los diversos asentamientos en sectores de cultivos -y no necesariamente en poblados de data colonial- permiten territorializar dichas áreas con atributos de identidades étnicas y familiares al venerar las cruces durante la medianía de cada año (Díaz et al. 2020).

También es importante destacar que, en algunos casos, la gestión de la festividad depende de la institución del alferazgo o la mayordomía, según el poblado y la región que corresponda. El cargo funciona como un dispositivo que representa a la comunidad y materializa la fiesta, pues no es solo su sostenedor económico, sino que, además, cataliza una serie de relaciones parentales y redes sociales que permiten articular la festividad durante el resto del año. En Chapisca, el alférez opera de manera explícita y debe ser asumido año a año por diferentes personas. Pero en Markirave no se ha constatado un sistema de cargos como el alferazgo, pues aquí, como en otras zonas del valle de Codpa, Azapa o Lluta, un linaje familiar se encarga de la celebración. Debemos considerar que el dueño de casa o líder de la familia es reconocido como "cabecilla de banda", coordinando la fiesta en gran medida junto con su parentela. En cualquier caso, estas figuras poseen una clara responsabilidad social y ritual dentro de la fiesta, asumiendo aspectos relevantes, como asegurar siempre la presencia de música durante todo el evento.

Dicho esto, debemos destacar el rol que poseen las bandas de bronces en las fiestas a las cruces. Son ellas las que, hace varias décadas, acompañan las fases rituales (ascenso al cerro, retiro de las cruces, descenso de las cruces, procesiones, vestimenta de las cruces, etc.) con diversas piezas musicales (adoraciones, alabanzas, himnos, huaynos, cumbias), marcando el ritmo y dotando de sentido a cada una de estas actividades ceremoniales. Cuando otros conjuntos o músicos (lakitas, orquestas) están presentes, rotan la participación articuladamente con las disposiciones de los "cabecillas" o del alférez. Los cantores locales también merecen una mención, pues se encuentran en Azapa, Codpa, Lluta y pueblos precordilleranos como Copaquilla, Socoroma, Pachama, Belén, Putre, Ticnamar, entre otros. Esta tradición colonial se sigue manteniendo e incluso se ejecutan cánticos en honor a la Cruz de Mayo distintivos de cada zona. Finalmente, las orquestas de cumbia andina también son una de las manifestaciones claves a la hora de realizar 
los momentos bailables durante la festividad y, si bien en Markirave no se presentan agrupaciones de este tipo, pues, como nos dijeron, "se aleja de su tradición", se interpretan cumbias con las bandas de bronces.

Sobre los campos sonoros para la congregación festiva, uno de los aspectos distintivos es su carácter performativo. La comunicación musical desplegada por las bandas, los cantores o la comunidad, puede ser entendida como una práctica que influye pragmáticamente en el ritual. Esto se constata en la función que posee la música y los sonidos al iniciar, marcar y diferenciar las distintas fases de las ceremonias, estableciendo fronteras temporales, espaciales y sociales. Así, la interpretación de una marcha, con todos sus atributos sociopolíticos o "chilenizadores", simboliza ahora en el despliegue del rito religioso el fin de una fase e inicio de otra, actuando como marcador temporal. Recordemos que, cuando se deben alzar las cruces (práctica) y comenzar la procesión hacia otro lugar (desplazamiento espacial) con toda la comunidad, los armónicos de las marchas conducen la movilidad de los celebrantes. Agreguemos que las alabanzas ejecutadas por las bandas de bronces o cánticos van marcando también los momentos de desplazamiento o detención en lugares sígnicos que la comunidad reconoce, donde los sitios silentes o silencios sonoros poseen atributos liminales al recorrer el paisaje andino.

Otra de las dimensiones es la escenificación. Como señalamos, la música es un acto que, en sí mismo, dado su contenido y estructura, hace posible el inicio y desarrollo de determinadas operaciones y fases rituales. No obstante, dicho despliegue sonoro debe ir acompañado de movimientos corporales, atuendos, reverencias, etc., como parte de una puesta en escena ritual. Es por ello que en el ingreso a los lugares considerados sagrados (cerros, calvarios, capillas), los saludos se expresan musicalmente a la Cruz y a las familias realizando venias y genuflexiones. Del mismo modo, las movilizaciones y los tránsitos durante las procesiones, las danzas tradicionales o melodías bailables (cumbias, huaynos), y un sinfín de otros elementos festivos, están indisociablemente vinculados a la ejecución sonora. No se trata de un aspecto secundario, sino que, muy por el contrario, forma parte de su ejecución ritual, permitiendo el desarrollo de las etapas de la fiesta. Estos movimientos corpóreos, esquemas o coreografías y dramatizaciones adquieren incluso una dimensión pedagógica, en la medida en que muchos de los asistentes reconocen en el despliegue de los músicos las pautas que deben seguir durante la celebración. No es menor el hecho de que los "cabecillas de banda" o alféreces contraten siempre bandas que conozcan todas las tradiciones comunitarias, que estén dispuestos a subir los cerros en procesión y danzar; es decir, que puedan realizar todas las costumbres andinas que van armónicamente unidas a la música.

Gracias al despliegue de esta dimensión musical es posible reforzar la asignación de roles dentro de los distintos ritos que se realizan durante la festividad. De esta manera, las prácticas musicales no solo son un indicador de lo que se debe hacer, sino que operan como un marcador asignado a y por los/as comuneros/as, reforzando los papeles que los indígenas asumen con los cargos religiosos. En Chapisca y otros pueblos andinos, la banda de bronces saluda al alférez y al "cabecilla" al llegar a la localidad, ratificando el protagonismo ritual de estos actores y el reconocimiento público del cargo que asumen al 'pasar fiestas. ${ }^{15}$ Algo similar ocurre cuando la banda entona los primeros "pies de cueca" destinados a los alféreces durante la fiesta, quienes deben bailar (sabiendo o no la coreografía) como parte del reconocimiento comunitario.

En definitiva, son todas estas dimensiones de sonoridades instaladas en el repertorio festivo y musical andino del norte chileno, en un contexto caracterizado por entramados de relaciones familiares, sociales y étnicas, las que se materializan en cada festividad, al subir los cerros sagrados para celebrar la Cruz de Mayo en los fértiles valles de Arica.

Reconocimientos Este trabajo se efectuó en el marco de los proyectos FondeCYT n. ${ }^{\circ} 1181844$ y 1191869 , y uTA Mayor 5792-21.

In memoriam yatichiri y colega Manuel Mamani, académico especialista en música aymara, con quien compartimos durante extensas jornadas de trabajo de campo y en numerosas reuniones en torno al estudio de las festividades y la música andina.

\section{NOTAS}

${ }^{1}$ Las bandas de bronces son un fenómeno social que está presente en diferentes poblaciones indígenas, campesinas o aldeanas de Latinoamérica y Europa. Cada una posee matices culturales e históricos propios, influenciados por elementos externos como las expresiones militares (Cohen 1997; Brufal 2008). Los casos de las bandas de bronces en Chile, Perú y Bolivia poseen características muy similares, pues la influencia musical alemana gravitó en su surgimiento en los tres países, respondiendo cada una a contextos socio- 
históricos particulares. Al respecto, véase D’Harcourt (1925), Romero (1998), Robles (2000) y Díaz (2009).

${ }^{2}$ Según el alférez, "la Cruz sale a recibir a la banda porque la banda tiene que hacer su entrada, porque también se presenta el cabecilla, que es la persona que está trayendo la banda, también presenta la banda". Las ceremonias que se realizan para el recibimiento de los músicos poseen una tradición de larga data en el área andina. Tiempo atrás, cuando se celebraban las fiestas patronales, los pobladores de comunidades cercanas acudían a la celebración invitados por los alféreces o mayordomos. Igualmente, asistían comparsas de lakitas de otros pueblos, por lo cual el pasante les brindaba la bienvenida en los calvarios y agradecía la participación con la "mesa ritual", en la cual todos compartían. Los músicos no recibían estipendio por su participación, solo la devoción a los santos los hacía movilizarse por las distintas localidades andinas, requiriendo la atención en alimentos. Los alféreces o mayordomos les daban frutos y verduras que cosechaban en las chacras consagradas a los santos, las que permitían solventar las festividades (Díaz et al. 2013).

${ }^{3}$ En pueblos como Socoroma, Belén o Putre, además de las bandas de bronces provenientes de las urbes, participan músicos y cultores locales que ejecutan melodías distintivas en honor a la Cruz de Mayo, e incluso cantan con guitarras y violines.

${ }^{4}$ En pueblos precordilleranos, como Copaquilla, la comunidad suele utilizar la sede social para la celebración, mientras que en Socoroma, las cruces son dejadas al interior del templo.

${ }^{5}$ Esquema de la estructura binaria ejecutada: A: antecedentes y B: consecuente (A----- B-----).

${ }^{6}$ Todas las transcripciones de la música a partituras corresponden a Manuel Mamani, quien dejó sus informes durante los últimos años de trabajo en terreno. Testimoniamos su legado con este tipo de estudios.

${ }^{7}$ Esquema de la estructura cuaternaria ejecutada: A: antecedentes y B: consecuente (A----- B-----), C: antecedentes y D: consecuente (A---- B-----, C----- D-----).

${ }^{8}$ Esquema de la estructura binaria ejecutada: A: antecedentes y B: consecuente (A----- B-----).

${ }^{9}$ Esquema de la estructura cuaternaria ejecutada: A y B, C y D (A----- B----- C----- D-----).

${ }^{10}$ De acuerdo con Rodomiro Huanca, cantor de Socoroma, una de las coplas del "cuculís" interpretadas durante la Cruz de Mayo es la siguiente: "Ahora sí que cantaremos, ahora sí que bailaremos / Ahora sí que cantaremos, ahora sí que bailaremos, cuculís, culis, culis / Canten, canten bailadores, verso no les faltará / Canten, canten bailadores, verso no les faltará, cuculís, culis, culis / Desde lejos he venido buscando flores de Mayo / Desde lejos he venido buscando flores de Mayo, cuculís, culis, culis / Buscando flores de Mayo, para coronar tu día / Buscando flores de Mayo, para coronar tu día, cuculís, culis, culis".

${ }^{11}$ Esquema de la estructura binaria ejecutada: A + B.
${ }^{12}$ El Pintatani corresponde a un tipo de vino dulce producido en el valle de Codpa desde la época colonial. Se consume principalmente en algunas festividades religiosas en la precordillera de Arica.

${ }^{13}$ La pawa (phawa), corresponde a una ceremonia aymara en la cual se extiende una llijlla o manto en el piso o en una mesa, según el lugar, y se depositan sobre ella hojas de coca, dulces, cigarrillos, botellas con alcohol y vino. Cuando se despliega la llijlla, recibe el nombre de mesa ritual, y en ella los pasantes -siempre un hombre y una mujer-y los asistentes por turnos y en parejas se acercan a la mesa ritual, piden a los mallkus, a la pachamama y a Dios que protejan a la comunidad y que se bendiga las ofrendas (telas para las cruces), para libar los licores a los cuatro puntos de la mesa, compartir las hojas de coca y esparcirlas. En ocasiones se acompaña con incienso y copal, junto a la música de las bandas.

${ }^{14}$ Cacharpaya: momento de despedida y finalización de la festividad. También se les denomina cacharpaya a los ritmos de huaynos o "trotecitos" de despedida que interpretan los músicos durante esta fase de la fiesta.

15 "Pasar las fiestas" significa asumir la responsabilidad de organizar las festividades en todas sus dimensiones y se inserta en el sistema de cargos religiosos, tales como alférez o mayordomo. Cuando una persona está iniciando la festividad, se utiliza la expresión "pasante", para indicar el rol y el significado ritual que ella posee durante los días de celebración.

\section{REFERENCIAS}

Barrientos, L. 1984. La Cruz de Mayo: Un ritual aymara en el interior de Arica. Revista Musical Chilena 38 (162): 119-124.

BRUfAL, J. 2008. Estudio de la trayectoria en educación musical de los componentes de sociedades musicales de Alicante: Vega Baja, Medio y Alto Vinalopó. Tesis para optar al grado de Doctor en Educación, Universidad de Alicante. $<$ http://www.cervantesvirtual.com/obra/estudio-de-latrayectoria-en-educacion-musical-de-los-componentesde-sociedades-musicales-de-alicante-vega-baja-medio-yalto-vinalopo--0/> [consultado: 12-07-2021].

Caro Baroja, J. 1979. La estación del amor. Fiestas populares de mayo a San Juan. Madrid: Taurus.

Conen, R. 1997. The musical society community bands of Valencia, Spain: a global study of their administration, instrumentation, repertoire and performance activities. Tesis para optar al grado de Doctor en Música, Northwestern University.

Dannemann, M. \& M. Quevedo 1994-1995. Música folklórica chilena: formas representativas actuales. Oralidad 6: 28-43.

D'Harcourt, R. 1925. La música de los incas y sus supervivencias. Lima: Occidental Petroleum Corporation.

DíAz, A. 2009. Los Andes de bronce, conscripción militar 
de comuneros andinos y el surgimiento de las bandas de bronce en el norte de Chile. Historia 42 (2): 371-399.

Díaz, A., L. Galdames \& R. Ruz 2013. De fiesta en fiesta. Calendario de festividades religiosas del norte de Chile. Arica: Ediciones Universidad de Tarapacá.

Díaz, A., O. Corvacho, W. Muñoz \& C. Mondaca 2020. Territorio, etnicidad y ritualidad afrodescendiente. La Cruz de Mayo en el valle de Azapa, norte de Chile. Interciencia 45 (3): 132-141.

Galdames, L., C. Choque \& A. Díaz 2016. De apachetas a cruces de mayo: identidades, territorialidad y memorias en los Altos de Arica, Chile. Interciencia 41 (8): 526-532.

Gómez, R. 2012. El ritual y la fiesta de la Cruz en Acatlán, Guerrero. Elementos 86: 33-40.

GonzÁlez, L. 1992a. Cuando nace la solidaridad: la cruz en las barriadas de Lima. En Cristo crucificado en los pueblos de América Latina: antología de la religión popular, F. Damen \& E. Judd Zanon, eds., pp. 235-250. Lovaina: Stauros-International.

GonZÁLEZ, L. 1992b. El comunero principal. La cruz en la vida campesina. En Cristo crucificado en los pueblos de América Latina: antología de la religión popular, F. Damen \& E. Judd Zanon, eds., pp. 211-234. Lovaina: Stauros-International.

Kuon, E. 2007. Cuzco: a las cruces las visten de fiesta. En Memoria del Cuarto Encuentro Internacional sobre Barroco: la fiesta, N. Campos, ed., pp. 193-202. La Paz: Siglo de Oro.

Mamani, M. 1988-1989. Rol de la música en el ritual, marca y floreo del ganado en el altiplano chileno. Diálogo Andino 7-8: 26-42.

Martínez, I. 2001. Los Mayos y las fiestas de primavera. Zenizate 1: 31-53.

Millones, L. 2001. La fe y el espectáculo. Breve historia de la vida ceremonial andina. En Perú: el legado de la historia, L. Millones, J. Villa Rodríguez \& D. Y. Arnold, eds., pp. 87-106. Lima: Universidad de Sevilla-Fundación El Monte-PromPerú.

Millones, L. \& H. Tomoeda 2011. La cruz del Perú. Sevilla: Universidad de Sevilla.

Molinié, A. 1997. Buscando una historicidad andina: una propuesta antropológica y una memoria hecha rito. En Arqueología, antropología e historia en los Andes. Homenaje a María Rostworowski, R. Varón \& J. Flores, eds., pp. 691708. Lima: Instituto de Estudios Peruanos.

Ramírez, B. 2009. La Fiesta de las Cruces, expresión del sincretismo cristiano-indígena. Revista del Instituto de Investigaciones Histórico Sociales 13 (22): 195-225.

RoBles, R. 2000. La banda de músicos: las bellas artes musicales en el sur de Ancash. Lima: Universidad Nacional Mayor de San Marcos.

Romero, R. 1998. Cambio musical y resistencia cultural en los Andes centrales del Perú. En Música: danzas y máscaras en los Andes, R. Romero, ed., pp. 21-60. Lima: Pontificia Universidad Católica del Perú.

SÁEZ, I. 2005. Movimientos populares, siglos XIX y xx. "Soy campesino y soy cantor", la fiesta de la Cruz de Mayo, un espacio de sociabilidad y conformación de identidad campesina, Aculeo 1960-2005. Tesis para optar al grado de Licenciado en Historia, Universidad de Chile. <http:// repositorio.uchile.cl/bitstream/handle/2250/110191/saez_i. pdf? sequence $=3$ \&isAllowed $=\mathrm{y}>$ [consultado: $12-07-2021$ ] .

Solís, E. 2004. Gotas de maíz: jerarquía de cargos y ritual agrícola en San Juan Tetelcingo, Guerrero. Ciudad de México: CIESAS.

TAмBiaH, S. J. 1985. A performative approach to ritual. En Culture, thought, and social action: an anthropological perspective, pp. 123-166. Cambridge, Mass.: Harvard University Press.

Uribe, H. 2008. La Cruz de Mayo, herencia cultural hispana. Breve estudio sobre su desarrollo en Lota, región del Biobío, Chile. Revista de Folklore 334 (28): 134-140.

VAn Kessel, J. 2006. 'Las cruces de Mayo', fiesta tradicional de los agricultores de Azapa. En Los santos íconos de Chile. Cuaderno de Investigación en Cultura y Tecnología Andina 24, pp. 17-28. Iquique: IECTA. <https://iecta. cl/wp-content/uploads/2020/03/Iecta-Cuaderno-deInvestigacio\%CC\%81n-en-Cultura-y-Tecnologi\%CC\%81aAndina-N\%C2\%BA-24.pdf> [consultado: 17-05-21]. 